\title{
Diversifying Electricity Customer Choice: REVing Up the New York Energy Vision for Polycentric Innovation
}

\author{
Joseph Nyangon and John Byrne \\ Additional information is available at the end of the chapter \\ http://dx.doi.org/10.5772/intechopen.76023
}

\begin{abstract}
Electric utility business models are changing to integrate new technologies and distributed energy resources (DER). Diversifying energy mix and customer choices are both novel and useful in understanding key drivers of this transformation, including distribution system planning and customer-service options. Practical implementation of these solutions, however, shows that without proper planning, energy diversification could come at very high social and economic costs. For example, regulators have been slow in implementing policy, regulatory, and business model constructs that promote customer choice to animate high levels of grid reliability and resiliency. Equally important is how viable existing utility business models are to navigating transformation processes, including strategic resource management, revenue model, customer interface, and value propositions. This chapter discusses our use of the Hamel business model to offer strategic analysis of Reforming the Energy Vision (REV), which is aimed at decarbonizing New York's energy sector and increasing customer choice and control. Specifically, we build from existing literature to argue that implementing distribution management systems (DMS) in which customer choice and DERs are prominent requires a shared or 'polycentric,' networked businessmodel innovations that build on competitive and comparative advantages of existing institutions to meet the growing demand for electricity services and utility strategic goals.
\end{abstract}

Keywords: reforming the energy vision, distributed energy resources, business model, polycentric innovation, utility choice management, Hamel framework

\section{Introduction}

The electric utility landscape is experiencing rapid and unprecedented transformation. A powerful confluence of structural, technological, and socio-economic factors is driving 
this change. Distributed technologies (e.g., distributed generation, energy storage, flexible demand, and advanced power electronics) are competing in the emerging distributed utilities market and, as a result, putting pressure on investors and regulators to consider utility choice management (UCM) opportunities that promote more capital-efficient options for the provision of electricity services [1]. The second installment of the Quadrennial Energy Review (QER), released in the winter of 2017, recommends spending $\$ 300-\$ 500$ billion in grid modernization, noting that it "is the platform for the twenty-first century electricity system, bringing significant value associated with lower electricity bills due to fuel and efficiency savings, more electricity choices, and fewer and shorter outages" [2]. The QER also recommends that utilities deploy a "wide range of new, capital-intensive technologies" to modernize their aging infrastructure, and to "support increased reliability, security, value creation, consumer preferences, and system optimization and integration at the distribution level." At the distribution utility level, the electric utility faces a fundamental challenge. Besides investments needed for grid modernization, the emergent role of the consumer as prosumer coupled with new priorities, such as enhancing electricity reliability, affordability, resilience, environmental protection, and grid security, are driving the current evolution in the industry and destabilizing the century-old government-regulated, vertically integrated, monopoly business model that is the energy utility.

The pressure to revamp the electric utility landscape is evident not only in the contiguous United States-for example, New York, California, Illinois, Massachusetts, and North Carolina-but also in Hawaii and Alaska [3]. The dominating trend of fast-flexing renewable energy sources, mostly solar and wind power, continues to underpin early retirement of baseload power-generating sources such as nuclear, coal, and natural gas steam generator [4]. The growth of solar and wind power, flat or declining electricity demand, and cheap natural gas have been cited as the reasons for the decline in electricity prices and economic viability of baseload energy generation sources such as nuclear energy [5, 6] and thus declining revenues for utility generators. As a result, strategic improvement of utility structure and planning to create new choices for customers requires explicit recognition and response to these challenges as well as local and regional idiosyncratic design and operational obstacles. For instance, utilities across the country face distinctive characterizations of the so-called 'death spiral' - the cycle of eroding market share to distributed energy prosumers that raises costs on remaining utility customers, leading to accelerated market losses [7, 8]. Nationwide, the 'death spiral' debate is substantial. According to Accenture, estimated utility sector revenue erosion in the United States resulting from increased distributed generation and gains in energy efficiency could be between $\$ 18$ and $\$ 48$ billion by 2025 , depending on status quo, demand disruption, or perfect storm assumptions [9] (Figures 1 and 2). However, this debate continues with varied levels of concerns across states and regional electricity markets like PJM Interconnection, Midcontinent (MISO), Texas (ERCOT), California (CAISO), New England (ISO-NE), and New York (NYISO). The effect of the dreaded 'death spiral,' if it materializes, will be felt differently across the nation's utilities. Similarly, aging infrastructure concern due to long periods of low investments in grid modernization, changing supply and demand profiles, and investments in research and development (R\&D) commitments are not geographically ubiquitous $[2,6,10]$. 


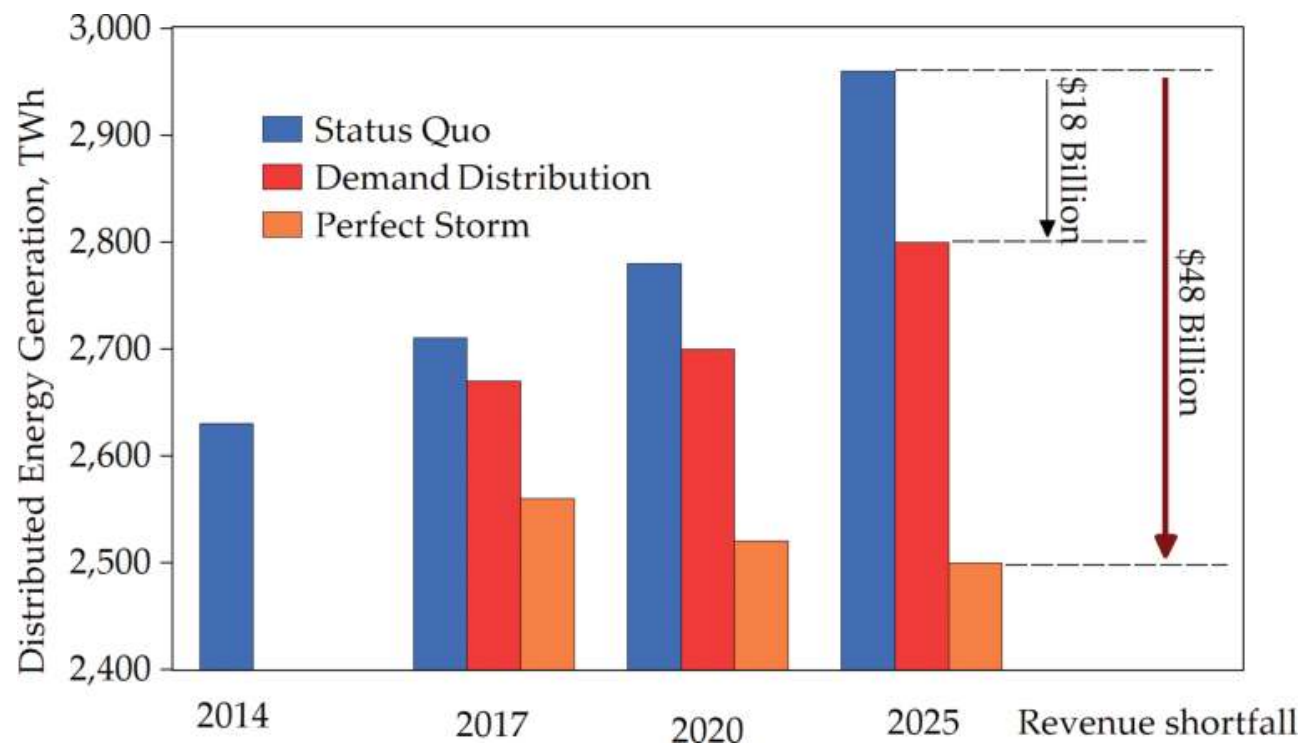

Figure 1. Estimated erosion of utility revenue.

Recent studies by McKinsey \& Company conclude that energy storage is already economical for many commercial customers [11]. Rapidly falling solar photovoltaics (PV) prices coupled with low-cost storage will create an increasing number of residential and commercial customers who will meet their electric service needs through distributed generation. Falling storage prices have the potential to transform the power landscape by smoothing out the variations in power associated with variable electricity power, such as solar and wind, and achieve 24/7 reliability. Frew et al. review pathways to a highly renewable U.S. electricity future and observe that design of policies such as renewable portfolio standard (RPS) targets, Federal Energy Regulatory Commission (FERC) orders, emission regulations, greater regional coordination and geographic aggregation, and energy storage is critical to the emergent distributed electricity market [12]. While there is disagreement on the structure of electricity market design, regional coordination planning, flexibility mechanisms required to help mitigate the variability and uncertainty challenges arising from a high penetration of intermittent electricity generation, and how soon and how fast a highly renewable electricity future can occur, the trend is similar for many parts of the United States.

Several response strategies have emerged shaped by policy, market, public oversight, and financing support. These include utility-as-platform models like the New York Public Service Commission's (NYPSC) grid and market modernization initiative called Reforming the Energy Vision (REV), utility as a smart integrator, and electric services operator model [13]. The New York's REV vision recognizes that the path for a distributed utility model which promotes a highly renewable electricity future in the state will not be linear. Hence, the vision lays out multiple sets of solutions to various aspects of electricity market design and operations, 


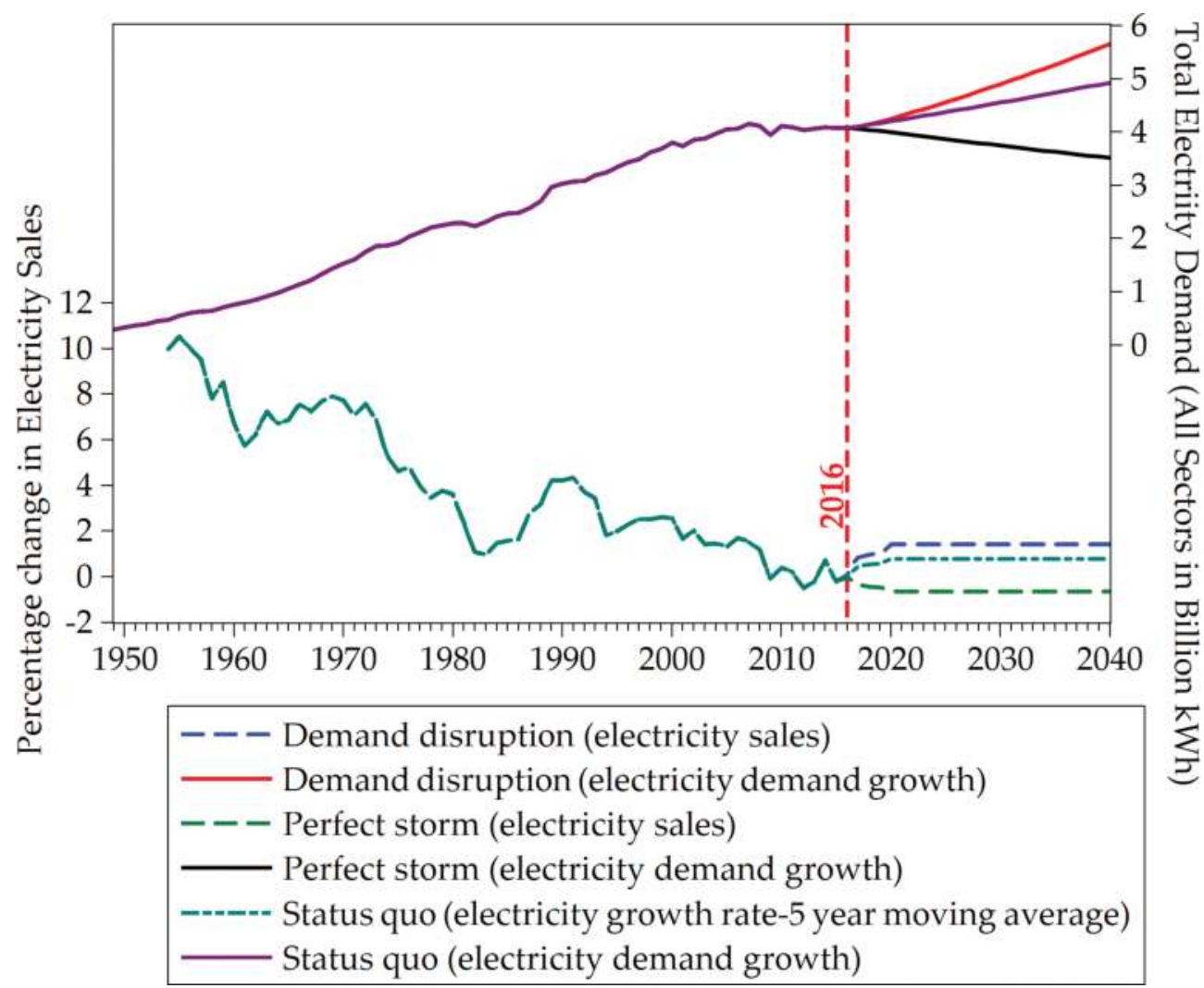

Figure 2. How the adoption of energy demand-disrupting technologies could erode energy demand and utilities' revenues through 2040.

taking into consideration utility market composition and regulatory structures. This paper evaluates a typology of policy, regulatory, and business model constructs for diversifying energy mix and utility choices, arguing for a polycentric approach to carry out utility businessmodel innovation and electric power market design that might allow this suggested future to play out in the real world. Section 2 discusses challenges, limitations, and opportunities of utility-side and customer-side business models. Section 3 evaluates the Hamel framework, and Section 4 applies this framework to the New York's REV. Section 5 concludes the paper.

\section{Theoretical framework}

\subsection{Business models}

The business model concept offers a valuable unit for evaluating new market ventures and business practice [14-16]. There is no universally accepted definition of a business model. However, authors in different industries have proposed a litany of definitions. Ref. [17] 
defines a business model as "the rationale of how an organization creates, delivers, and captures value" while [18] describes a business model as "the heuristic logic that connects technical potential with the realization of economic value." Ref. [19] defines a business model as "a representation of the underlining core logic and strategic choices for creating and capturing value within a value network." As an analytic tool, the concept has been widely used in studying investors' preference for service-driven business models [15], energy service company (ESCO) [16], micro-generation solutions [20], the distributed electricity generation market [21], energy efficiency programs [22], evolution of energy utilities [23], and the ongoing expansion of distributed electricity generation market [24]. As a result, the business model concept has been widely tested in practice in the energy sector. Common components of the business model include the value chain, value propositions, target markets, competitive strategy, revenue-generation models, customer interface, value network, and infrastructure service $[18,25]$.

\subsection{Business-model innovation}

Business-model innovation as a term remains largely vague. Reference [25] notes that business-model innovation is less a matter of superior foresight, but more of trial and error and expost adaptation. Reference [26] suggests that it entails business model experimentation, while [27] views it as a strategic renewal mechanism for organizations undergoing through periods of transformation in their external environment [28]. In this chapter, business-model innovation refers to the development of new organizational forms to create, deliver, and capture value for realizing a distributed utilities future. Electric utilities in New York and elsewhere have different starting points, value propositions, customer expectations (across customer classes), and priorities, and they vary significantly with respect to electricity revenues, electricity sales, and customer-base. How can utilities meet these demanding business expectations in an uncertain environment? Fox-Penner (2010) offers a solution through a "two-and-a-halfbusiness model" innovation as an alternative $[13,28]$. The half refers to a smart integrator scenario in which the utility operating the power grid does not own or sell the power delivered by the grid. Consequently, power generation and grid infrastructure development including its information and control systems are community-owned (e.g., a community micro-grid). The advantage of a community-owned distributed generation is its potential for economies of scale. Hundreds to thousands of customers join the network participating as both consumers and producers (or prosumers) of renewable electricity from sources like solar PV and wind turbines. These prosumers use the set operational standards, but the financing and administration side of the business model is handled separately by the utility.

With that in mind, our research shows that aligning core business incentives of electricity distribution utilities with cost-effective integration of DERs into power systems is a prerequisite for achieving DMS and UCM business model constructs that might allow this future to come about, arguing for a 'polycentric' approach in the near term. As a preliminary matter, it is commonly noted that the smart integrator model has well-developed analytic capabilities to ensure the electric grid can meet electricity demand at all times. The smart integrator model also has a green dispatch mechanism that enables utilities to determine when and how to switch to low-carbon energy sources such as solar, wind, and hydroelectric power. Therefore, the only key obligation of the utility is ensuring that the local grid meets power demanded in 
the system. Second, the smart integrator has a "highly secure but maximally open platform for information, price, and control signals" [13]. This feature ensures that it responds well to different regulatory regimes by integrating information for accounting, billing, and settlement systems to accommodate the more complicated functions such as managing pricing plans, payment, and billing. Related to the smart integrator model is the energy services utility (ESU), which is an extension of the smart integrator model. In the ESU model, the focus of the utility shifts from being a purely asset- and commodity-driven entity to a service and value-added enterprise in which profit achievement hinges on the services offered to consumers $[13,15,28]$. Examples of the ESU business model include programs offered by Arizona Public Service Electric Company (the largest electric utility in Arizona), including energy storage, demand response, and load management.

Under a smart integrator, utilities must consider creating different triads of structure, regulation, and revenue models to facilitate transformation to a distributed utilities future. This process requires a variety of innovations, including joint construction and developments of electricity generation and delivery of electricity services such as financing and building related assets, ownership, and operations; growth of diversified independent transmission companies; diversified of generation mix with high composition of low-carbon resources mostly from natural gas and renewables such as hybrid solar PV systems, polygeneration energy systems, or zero-net energy systems; use of subsidiaries to speed up clean energy diversification; and use of utility consortia that expand member utilities' service offerings beyond the provision of electricity service (e.g., to cater to cooperative customers).

\subsection{Utility-side versus customer-side business model}

Two principal factors concern utilities. First, electricity must get to the customer reliably and safely. Second, power must be delivered efficiently to maximize profit margins. These factors put pressure on struggling utilities to minimize electric grid system losses. Utility-side business models, concepts, components, and technologies therefore ought to take these factors into consideration. With the growth of prosumers, the challenge then becomes: which key policy, market, and business concerns should utilities prioritize? Other salient challenges include optimal deployment of expensive assets, need for diversification of generation, demand response management, grid stability, and tariff implementation. Some of these challenges can be addressed by deploying 'smart' technologies at the utility-side to monitor operations and improve billing and tariff management. In states with fast changing electric utility landscapes such as New York, however, regulators need to identify and deconstructed elements of innovations in a contextually-appropriate manner to assure scalable solutions.

Ref. [29] examines a suite of wholesale power market design currently in use on the customerside to improve electricity reliability, security, and flexibility. It also assesses feasibility of wholesale market design with high penetration of DERs considering the role of technological innovations such as demand response, distributed generation, and energy storage. These technologies support the infrastructure needed to provide electricity services and address critical challenges such as climate change, energy security, and revenue erosion [2]. The revenue erosion concern can also be addressed through customer-side renewable electricity business models. In this chapter, distributed generation systems refers to small-scale generation systems (e.g., for private customers and small- to medium-sized businesses) in the range of a 


\begin{tabular}{|c|c|c|}
\hline & Customer-side business model & Utility-side business model \\
\hline Customer interface & $\begin{array}{l}\text { - Better customer relationship needed to } \\
\text { develop new value propositions. } \\
\text { - Changes in customer segments. } \\
\text { - New channels are needed. } \\
\text { - Customer hosts energy generation system } \\
\text { and shares the benefits with the utility. } \\
\text { - Long-term customer relationship. }\end{array}$ & $\begin{array}{l}\text { - Utility-customer relationship remains } \\
\text { unchanged. } \\
\text { - Customer segmentation leads to increased } \\
\text { customer base and "eco" price premium } \\
\text { earnings. } \\
\text { - Channels remain the same } \\
\text { - Electricity is treated as a commodity. } \\
\text { - Customer does not host energy generation } \\
\text { - } \text { cystems. }\end{array}$ \\
\hline Value proposition & $\begin{array}{l}\text { - Shift from commodity delivery to energy } \\
\text { service provider. } \\
\text { - New value propositions needed for the } \\
\text { market. }\end{array}$ & $\begin{array}{l}\text { - Bulk generation of electricity supplied to } \\
\text { the grid. } \\
\text { - Additional energy related services and } \\
\text { customer value. }\end{array}$ \\
\hline Infrastructure & $\begin{array}{l}\text { - Large number of small-scale assets. } \\
\text { - Generation close to consumers. } \\
\text { - } \text { Experienced in small-scale energy } \\
\text { - Projects. } \\
\text { Partnerships with system suppliers and } \\
\text { local installers. }\end{array}$ & $\begin{array}{l}\text { - Small number of large-scale assets. } \\
\text { - Centralized generation. } \\
\text { - Experienced in large-scale infrastructure } \\
\text { projects. } \\
\text { - Partnerships with project developers and } \\
\text { suppliers. }\end{array}$ \\
\hline Revenue model & $\begin{array}{l}\text { - Revenue from direct use, feed-in and/or } \\
\text { from services. } \\
\text { - High transaction costs reduce profit } \\
\text { margins. } \\
\text { - New revenue models needed. } \\
\text { - Complex electric cost structure more due } \\
\text { to many small investments instead of few } \\
\text { large investments. }\end{array}$ & $\begin{array}{l}\text { - Revenues through feed-in of electricity. } \\
\text { - Economies of scale from large projects and } \\
\text { project portfolios. } \\
\text { - Revenue models are available. } \\
\text { Electric cost structures are in favor of utili- } \\
\text { ties experiences with large-scale infrastruc- } \\
\text { ture financing. }\end{array}$ \\
\hline
\end{tabular}

Table 1. Utility-side versus customer-side business model.

few kilowatts to about $5 \mathrm{MW}$ from sources such as solar PV, micro-wind turbines, and microcombined heat and gas-power systems. Accordingly, customer-side and utility-side business models follow a very different logic in the value chain: the former is based on many small projects while the latter focuses on a small number of large projects. Table 1 summarizes the differences of the two models [30, 31].

Unlocking greater value of distributed utilities requires new business models that improves ownership, asset management, and monetization of utility assets. In the utility-controlled and utility-owned value arrangement, utilities continue to execute their core competency functions, for example, asset ownership and operation. For instance, New York State's (NYS), clean energy standard (CES) provides for a " 50 by 30 " goal, which commits the state to 
procure $50 \%$ of its electricity from renewable resources by 2030. Each load-serving entity is required to procure for their retail customers renewable energy credits (RECs) linked to DERs listed in Tier 1 (e.g., solar, wind, biomass, and pumped storage hydroelectric) [32]. Likewise, the customer-side structure provides a context in which to situate the RECs' management; utilities can bundle these RECs into service programs, such as utility green pricing plans, and sell them to other parties.

\section{The Hamel framework for utility business model evaluation}

A fundamental challenge facing New York today is how to generate richer innovations at all levels, including products, business models, and management systems that transform a centralized power system into a high-performing distributed utility sector. The critical challenge in this endeavor, however, entails fashioning a comprehensive analytical framework that captures components of business model across the entirety of the market spectrum. To avoid the pitfall of ambiguous strategy in such a framework, a service-based business model approach should be adopted. Ref. [33] identifies six key functions of business model strategy as value proposition, revenue generation mechanism(s), value chain, value network, target market, and a competitive strategy, while [19] lists the four often-cited business model components: strategic resources, value creation, value capture, and value network. Hamel business model [34], which is applied in this chapter, incorporates these fundamental features, providing a robust framework (Figure 3) for analyzing the REV vision. It appears that REV is based on a polycentric paradigm as the main pathway with which utility market reorganization will be navigated. Several studies have already explored UCM governance approaches with polycentric characteristics, e.g., [35-39]. These contributions largely focus on bending reality, business model constructs, and institutional and near-term governance as an impetus for polycentric innovation. We argue here that so long as utility regulation and governance lag behind technology innovation, institutional innovations needed to support the industry to "become more adept at generating richer innovations at other levels, including products, services, business models, and management systems," will continue to play catch up thus impeding the full participation of DER resources [40].

Hamel's business model is comprised of four major components (i.e., core strategy, strategic resources, customer interface, and value network), three bridge components (customer benefits, configuration, and company boundaries), and sub-elements that determine the profit potential (efficiency, uniqueness, fit, and profit boosters). The first component, a core strategy, is the essence of how a firm chooses to compete. The sub-element, or the business mission, captures the overall objective of the strategy or what the business model is designed to accomplish or deliver. According to the Hamel framework, the business mission defines the decisions of a firm, such as the value proposition, strategic intent, purpose, goals, and overall performance objectives. Therefore, when a company changes its business mission, this does not necessarily imply innovation in business concept.

The product/market scope defines where the firm competes (i.e., the firm's competitive arena). For instance, the scope determines the customers, geographies, and product segments [38]. In this regard, the definition of product/market scope can be a source of business concept innovation for a firm-especially when it is entirely different from that of traditional 
competitors [34]. Finally, basis for differentiation captures how the firm or organization competes differently from its competitors. For instance, a firm differentiates itself from competitors by seeking answers to questions such as: how do opponents differentiate themselves in the electricity market (e.g., in designing utility revenue models such as platform service revenues, rate design, and customer energy data usage)? Are there other dimensions of marketoriented revenue model differentiations that could be explored? In what aspects of the energy service (e.g., rate design) has there been the least differentiation? How could differentiation be increased in some of these dimensions (e.g., by implementing opt-in rate initiatives such as time-of-use rates or smart home rates)? And have differentiation opportunities been diligently sought in every dimension of the business model?

Hamel's second major component, strategic or unique firm-specific resources, constitutes a source of competitive advantage. Fundamentally transforming the market to increase renewable electricity generation in New York is a source of business concept innovation. A successful business model thus creates its own intellectual hegemony. Strategic resources embody core competencies, and comprises skills and unique capabilities. Strategic assets depicts what is owned by the firm. They are rare and valuable things other than know-how, and include brand, patents, infrastructure, proprietary standards, and customer data. A prudent firm-wide use of strategic assets can lead to business concept innovation. According to [41], asymmetry in the resources a firm controls and discretionary managerial decisions about resource development and deployment can be sources of sustainable economic rent. On the other hand, core processes illustrate what people in the firm do. They are methodologies and routines used in translating competencies, assets, and other inputs into customer value. A reconfiguration of central components and core processes in the business model therefore constitutes business concept innovation [42].

The third major component of the Hamel framework is customer interface. It is comprised of four elements: (a) fulfillment and support, which describes market access (i.e., how the firm reaches the market and it includes channels, customer support, and service levels); (b) information and insight, which refers to knowledge that is collected from customers and the ability of the organization to extract insights from this information to design new products and services for customers; (c) relationship dynamics refers to the nature of interaction between the firm (producer) and the customers; and (d) pricing structure specifies the revenue mechanism for monetizing services rendered (i.e., flat-rate charges or charges based on TOU).

The fourth component is the value network of the firm. This includes suppliers, partners, and coalitions that complement and strengthen organization's resources. Suppliers typically reside "up the value chain" from the producer [34]. The configuration of activities is a bridge component that links the organizations' core strategy to its strategic resources. Configuration of activities specifies unique ways in which core competencies, strategic assets, and core processes interrelate to support a chosen strategy and how those linkages are managed in order to achieve greater value. Intermediating between the core strategy and customer interface is another bridge component-the customer benefits - which describes the bundle of benefits that is essentially offered to consumers. Company boundaries refers to decisions regarding what the firm does internally based on what it contracts out to the value network.

At the base of the framework are four factors that define the utility of the Hamel business model. Efficiency guarantees that the value of benefits delivered to customers exceeds their 


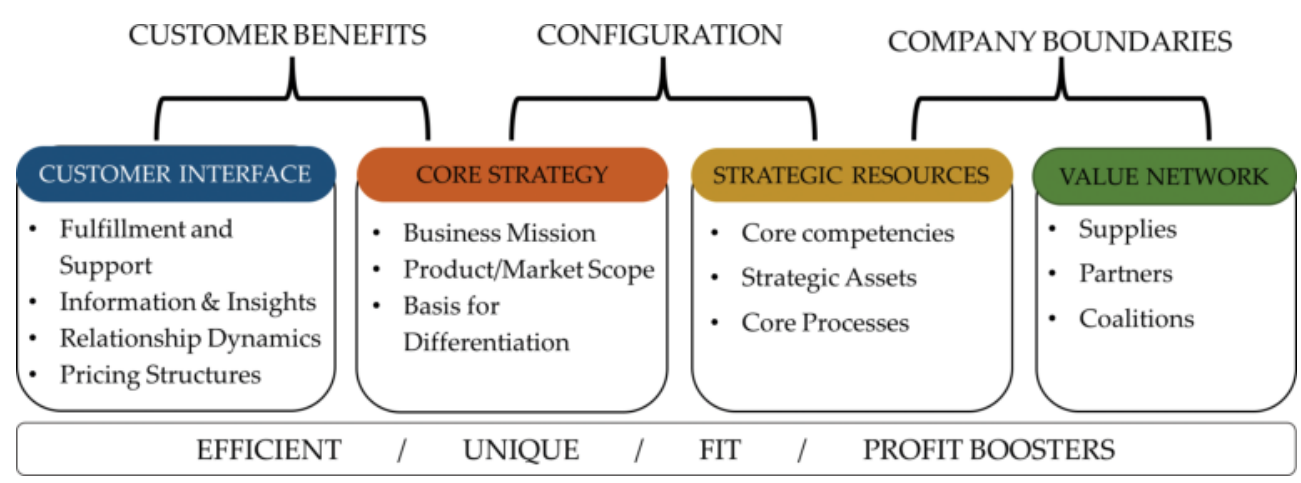

Figure 3. Components of Hamel business model framework.

production costs. Uniqueness demonstrates the level of convergence among business models in terms of conception and execution in ways that add valued to customers; the greater the convergence among business models, the lower the potential for above-average profits. Fit means that all the elements of the business model are consistent and mutually reinforcing, and that all the parts work together for the same end goal. Finally, profit booster(s) include increasing returns, competitor lock out, strategic economies, and strategic flexibility. Positioning the Hamel business model as the unit for analysis of market reorientation in electric industry thus provides a robust and multi-dimensional framework for evaluating the suitability of new proposals for electric utilities and energy governance in in New York.

\section{Evaluating the REV docket: the détente for utilities and DER}

Initiated in 2014, New York's REV program is a comprehensive effort to reform the state's energy system in order to align ownership, management, and operation of its utility industry $[43,44]$. REV is led by NYPSC and seeks to fundamentally transform the electric power sector of New York State from a primarily centralized generation system to distributed utilities model [45]. The REV docket has two tracks. Track 1 focuses on the development of DER markets and the utility-as-platform model known as distributed-system platform (DSP) providers, while Track 2 focuses on reforming utility-ratemaking practices and revenue streams to accommodate the proposed DSP model. Implementation of REV will take several years and will involve the mutual efforts of industry, customers, non-profit organization, and regulatory partners. The initiative encourages regulatory changes that promote energy efficiency, demand response, increase storage capacity, and increase renewable energy resources. These reforms empower end-users by providing more choices through diversification of energy resources, and by fostering improvement in the performance of the power sector across policy objectives such as system-wide efficiency, system reliability and resiliency, enhanced customer billing system, market animation and leverage of customer contributions, fuel and resource diversity, and reduction of carbon emissions [44]. 
Richard Kauffman, chair of the state's Energy Research Development Authority (NYSERDA) and former NYPSC Chair Audrey Zibelman explain that the REV program is "removing market barriers and bridging market gaps that have historically impeded the clean energy sector from benefiting from technological innovations" [46]. Its major impact on the industry so far has been increased integration of solar- and wind -energy generations. Therefore, this evaluation focuses on the regulations and directives specified by the NYPSC, and other guidelines released by key power utilities in the state [e.g., Consolidated Edition, Long Island Power Authority, Niagara Mohawk Power Corporation, New York Power Authority (NYPA), New York State Electric and Gas Corporation (NYSEG), Central Hudson Gas and Electric Corporation (CHGEC), Orange and Rockland Utility Inc., and Rochester Gas and Electric Corp (RG\&E)] to explore the characteristics, nuances, structure, and approaches applied.

\subsection{From centralized models to distributed system platforms}

Retail peak electricity demand in NYS is approximately $75 \%$ greater than the average system load, and nearly $9 \%$ of power generated in the state is lost in transmission [47]. Essential investment needed through 2025 to replace the state's aging infrastructure to meet projected energy demand is estimated at $\$ 30$ billion [43]. REV is thus a 'polycentric' strategy intended to make distribution planning more transparent and better integrated. For instance, it seeks to transform electric distribution companies into DSP providers with responsibility for active coordination of DERs. It fosters "transactive energy" ecosystem in which "consumers and other parties can take full advantage of every type of energy resource-on both sides of the meter" [45]. Key to this ambitious goal is reorienting the traditional regulatory model by aligning utility and consumer interests so that both groups benefit from (scalable) improved market efficiency and scalable organizational learning.

Two pricing mechanisms offer a critical role in this regard. First, REV establishes benefit-cost analyses as a foundational procurement tool to determine renewableelectricity deployment [48]. Chosen due to its regulatory familiarity and apparent simplicity [49], the multi-year distribution system integration plans (DSIPs) to be developed by utilities seeks to foster a fair, open and value-based decision-making environment for utilities to build out their own competitive advantage in the DER market [45]. The benefit-cost approach will be applied in DSP investments, procurement of DERs through competitive selection and tariffs, and energy efficiency programs. Second, REV proposes using locational marginal pricing (LMP) principles to optimize the value of distributed utilities. Application of LMP principles can help distinguish which configuration of distributed resources enhances system flexibility and yield overall best value to consumers [44]. In terms of a repurposed DER policy, market development, innovation in designing value strategy and benefit-cost of DSIPs, and investment in community-choice aggregation programs, the REV model shares some of these characteristics with other ambitious and successful initiatives, particularly the German Energiewende initiative [50]. New York is not alone in its efforts to improve its utility regulation market and optimal system efficiencies. Parallel regulatory actions have been proposed in California, Hawaii, Massachusetts, Minnesota, and Illinois through its proposed utility of the future study known as "NextGrid" [51]. However, REV represents the most promising utility-as-platform business 
model as it challenges two fundamental components of the conventional utility model: the assumption that electricity demand is inelastic, and the notion that economies of scale make a centralized generating model the most economical way for electricity services provision [52] and market development. Table 2 summarizes the main policy, regulatory, and technological solutions that utilities and planners have proposed to improve DMS and UCM strategies based on polycentric approach to business-model innovations.

\subsection{Application of the Hamel Framework to the REV Docket}

Table 3 offers a four-part, multi-dimensional, Hamel analytical framework and application of the key dimensions to REV. These dimensions extend beyond business-model innovation in the utility industry. These dimensions attempt to account for the increasing focus on performance-based utility operation, the relationship dynamics that accompany such a shift [58] and the required transition to a servitization system - as mandated by system reliability and resiliency, system-wide efficiency, and the climate change challenge [3].

\subsubsection{Strategic resources and opportunities: utility assets}

There are four main types of electric utilities in NYS, namely investor-owned private utilities, retail-power marketers, state-owned public authorities, and municipal utilities. These utilities can be grouped into two service types: bundled and delivery. Several organizations have institutional capabilities, mandates, and responsibilities for managing utility customer choice archetypes in New York (Figure 4). Eventually, NYSERDA may emerge as the hub of such polycentric activities. However, a more polycentric governance approach could potentially emerge across and between several bodies as institutional innovation takes root, with organizations such as the NYPSC and FERC providing oversight mechanisms for greater transparency in utility rate design, wholesale market regulations, and DER integration, and organizations like the North American Electric Reliability Corporation (NERC) and New York State Reliability Council (NYSRC), establishing greater degrees of reliability standards. This polycentric innovation development could help minimize information asymmetries and

\begin{tabular}{ll}
\hline Policy, regulatory, and technological solutions for advancing polycentric innovation & Author(s) \\
\hline $\begin{array}{l}\text { Information asymmetry, capital expenditure bias, and time-varying rates. } \\
\text { Distribution utilities and their place in an integrated grid model to provide infrastructure services, } \\
\text { enhance personalization, and value creation. }\end{array}$ & {$[1]$} \\
$\begin{array}{l}\text { Energy performance contracting, regulation of retail energy markets, and innovation of revenue and } \\
\text { pricing models. }\end{array}$ & {$[16,55]$} \\
$\begin{array}{l}\text { DERs, DSPs, benefit-cost analysis framework, and net energy metering. } \\
\text { Institutionalized polycentric innovations in energy governance, and sociotechnical co-evolution of } \\
\text { energy planning and policymaking. }\end{array}$ & {$[3,55,56]$} \\
Marginal-cost-based dynamic pricing and time-varying electricity rates. & {$[47]$} \\
$\begin{array}{l}\text { Utility financial incentives, investments, utility of the future roadmaps: (smart grid development, } \\
\text { DERs, and customer utility service model). }\end{array}$ & {$[45,57]$} \\
Electric grid modernization and polycentric governance (democratized energy paradigm). & {$[45,46]$} \\
\hline
\end{tabular}

Table 2. Policy, regulatory, and actions for polycentric innovation. 


\begin{tabular}{|c|c|c|}
\hline Component & Definition & REV features \\
\hline $\begin{array}{l}\text { Strategic } \\
\text { resources }\end{array}$ & $\begin{array}{l}\text { Depicts the architecture of the utility value } \\
\text { creation. Includes strategic assets, know-how, } \\
\text { core processes and competencies. }\end{array}$ & $\begin{array}{l}\text { An estimated } \$ 30 \text { billions of investment in the } \\
\text { state's aging grid infrastructure is required by } \\
2025 \text {. } \\
\text { NYSERDA's Clean Energy Fund provides } \$ 5 B \\
\text { investment in new green energy over } 10 \text { years, } \\
\text { starting in } 2016 \text {. }\end{array}$ \\
\hline $\begin{array}{l}\text { Customer } \\
\text { interface }\end{array}$ & $\begin{array}{l}\text { Greater customer interactions, including } \\
\text { customer relationship, segmentation, fulfillment } \\
\text { support, and revenue structure. }\end{array}$ & $\begin{array}{l}\text { REV promotes greater consumer choice. } \\
\text { Emphasizes enhanced customer-centric } \\
\text { paradigm (e.g., billing solutions for effective } \\
\text { management). } \\
\text { Nonlinear transactions. }\end{array}$ \\
\hline Value network & $\begin{array}{l}\text { Includes utility added values or business } \\
\text { offerings to resource providers, suppliers, and } \\
\text { partners. }\end{array}$ & $\begin{array}{l}\text { Removes market barriers and promotes } \\
\text { distributed utilities. } \\
\text { Promotes greater interaction among DSPs to } \\
\text { create a market pricing platform, and service } \\
\text { monetization. }\end{array}$ \\
\hline Core strategy & $\begin{array}{l}\text { The utility's capacity to change course in the face } \\
\text { of potential existential business model risks. } \\
\text { This capacity is influenced by the flexibility and } \\
\text { complexity of both the business model but also } \\
\text { the infrastructure it operates. }\end{array}$ & $\begin{array}{l}\text { Distribution utilities act as DSPs. } \\
\text { Energy efficiency savings are part of utility } \\
\text { revenue not dedicated surcharge. } \\
\text { Earning impact mechanisms (EIM) replace } \\
\text { platform service revenues (PSR) and market } \\
\text { based earnings (MBE). } \\
\text { Includes modified clawback mechanisms to } \\
\text { attract third parties. } \\
\text { Encourages time of use (TOU) rates. } \\
\text { Each utility submit benefit-cost-analysis plan. }\end{array}$ \\
\hline
\end{tabular}

Table 3. Application of Hamel business model to conventional energy utility.

strategic behavior such as disguising true expected future costs to the regulator to increase allowed revenues or returns. As the NYPSC contends, "asymmetry regarding system information if continued will result in a barrier to new market entry by third parties and ultimately impede innovation and customer choice" [44]. On the other hand, New York Independent System Operator (NYISO) - a non-profit organization set up by NYS-could emerge as the central open platform for procuring DERs from suppliers. NYISO currently administers wholesale electricity markets in the state and provides reliability planning for bulk-electricity power, but this function could expand with the growth of DERs especially bulk power generation. Ultimately, NYISO would continue to oversee the wholesale electricity markets in NYS while FERC regulates wholesale electricity rates, licenses hydroelectric projects, and sets policies for interstate electricity sales. Under FERC Order 745, FERC regulates wholesale product tariffs by independent system operators (ISO) such as NYISO-including integration of DERs into wholesale markets [45].

The state's strategic resources and utility assets are owned, operated, and regulated by a variety of private and public entities (Figure 4). The functions provided by this complex electricity infrastructure create a path dependency in which existing business models either enable 
or constrain energy market development. The resulting utility landscape that manages the flows of all these energy resources has experienced consolidation to the point at which, in 2015, a "baker's dozen" of three holding companies (namely Consolidated Edition, Long Island Power Authority, and Niagara Mohawk Power Corporation) representing $2.4 \%$ of all integrated utilities controlled $49 \%$ of utility revenues [4]. The REV model fully addresses the subcomponents of strategic resources (core competencies, strategic assets, and core processes) of the utility industry such as the aging infrastructure challenge. It supports what Reference [59] refers to as "infrastructure to services transition", or the "evolution of infrastructure for commodity delivery" to support greater personalization of value-new purposes, new platforms, enabled new infrastructure, and new applications (services).

\subsubsection{Customer interface: increasing customer choice and control}

REV empowers customers with meaningful level of choice and reduces cost-of-service of electricity consumption. For instance, it improves electricity billing system and knowledge of customer analytics, and animates the market with substantial choice offering about the consumption and provision of electricity services (e.g., from whom to procure electricity services and from what resources) [45,46]. Conventional electric utilities compete by establishing utility-consumer relationship characterized by billing-based interactions that are impersonal, distant, and standardized. This distant aspect arises partly due to primary fiduciary obligation

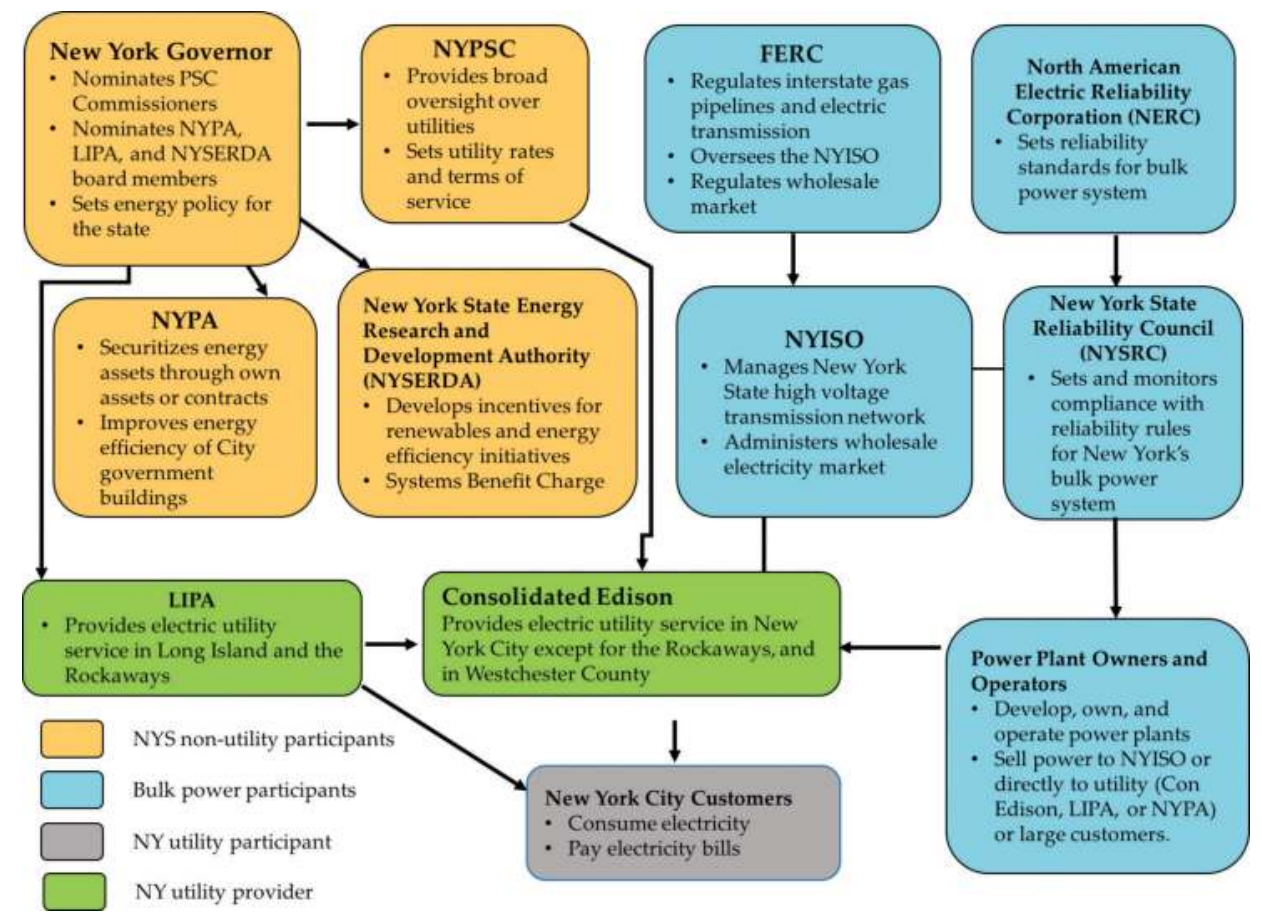

Figure 4. NYS electric industry participants and institutions. 
to the owners and shareholders of the company. Additionally, conventional utilities are characterized by less customer interactions as they do not go "beyond-the-meter."

Fundamental to optimizing behind-the-meter storage assets and DERs like rooftop solar is sharing of distribution-level data of the utility grid and common understanding of its distribution system. In 2015, a total of 124 utilities operated in New York with investor-owned utilities accounting for $12 \%$ of the total market share, representing $71 \%$ of customers (Figure 5). Behind the meter, cooperative, municipal, retail power marketer, and state utilities accounted for $9.7,0.8,9.7,65.3$, and $2.4 \%$ of the total market ownership, respectively. Investor-owned utilities operate under conditions of a guaranteed rate of return that is set by NYPSC. In the conventional business model, utilities invest in large-scale asset, economies of scale, and long-term infrastructural commitments that determine the form of the revenue/cost structure. These features still influence portfolio of electricity sales, revenues, and customer numbers of certain utilities in New York, even as the implementation of the REV model is ongoing. Behind-the-meter recorded the fastest growth in electricity revenues, sales, and customer count of $89.4,78.6$, and $68.7 \%$ in 2015 , respectively. Under REV, DSP providers "create markets, tariffs, and operational systems to enable behind the meter resource providers to monetize products and services that will provide value to the utility system and thus to all customers" [43].

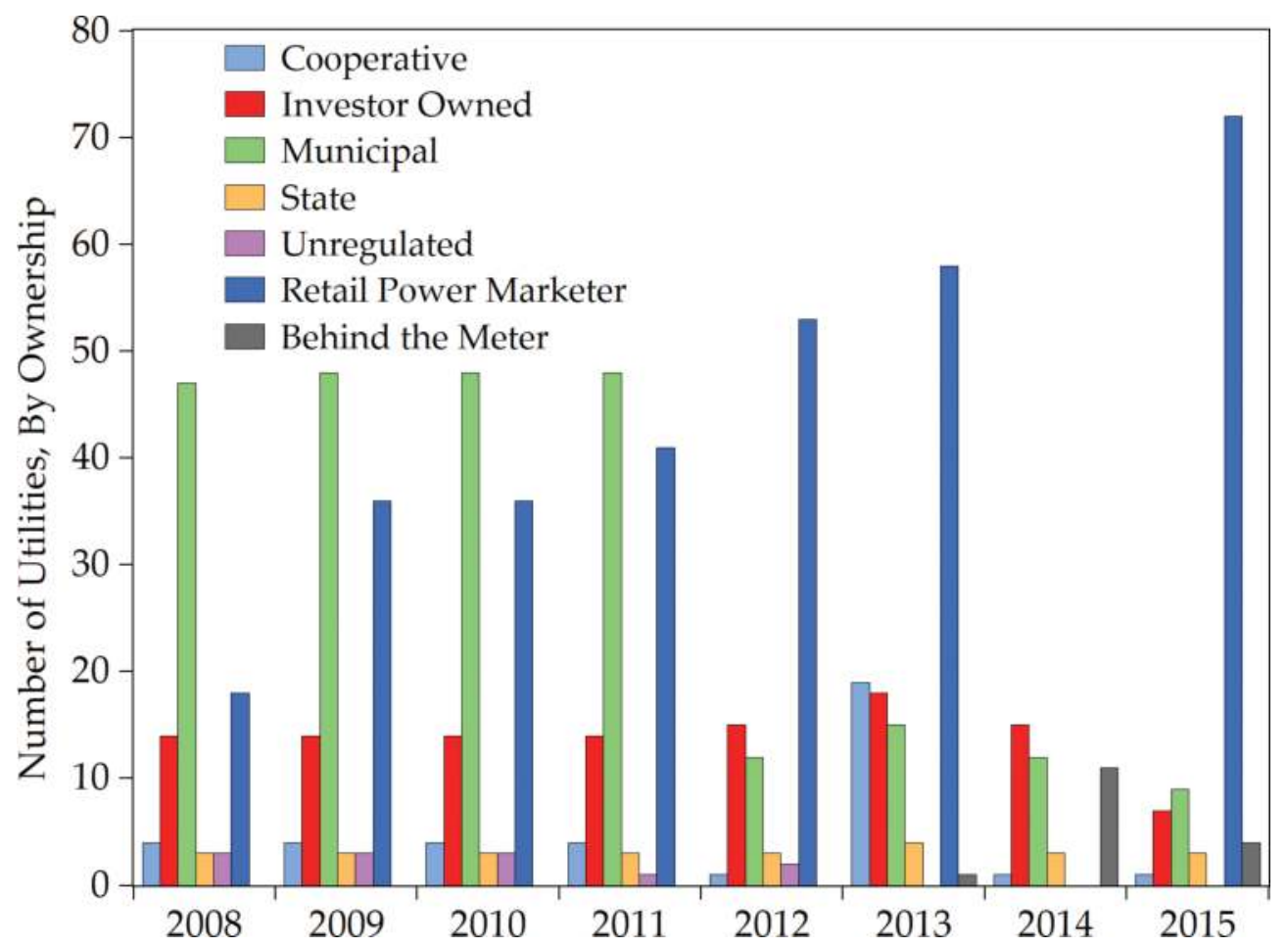

Figure 5. Number of utilities, by ownership from 2008 to 2015. 


\subsubsection{Value network: expanding customer-base}

The business model of the traditional utility pursues expansion in asset-based and, through its commodity-focused strategy, increases shareholders value. The goal of the conventional utility, as such, can be conceptually positioned at one end of a profit-motivation spectrum: the "motivation to build incremental assets for the primary purpose of expanding its ratebase" [60]. Because regulators reward or chastise utilities for decisions to achieve certain public-policy goals and to maintain "just and reasonable revenues," this model faces mounting challenges-especially in a DER framework. So-called "incentive regulation," however, establishes the working conditions of the utility. Within these conditions, "[g]iven any set of regulations, utilities participate in actions which most benefit their principal constituenciesshareholders and management-while meeting the requirements of the regulations" [61]. Because the principal constituency of the investor-owned utility is its shareholder base, REV seeks to expand utility customer-base through value addition to scaling economic efficiency.

\subsubsection{Core strategy: animating business-model innovation}

All the major distribution utilities in New York support the REV vision for long-term innovation in the industry and have submitted proposals for pilot projects. Additionally, a number of utilities have began implementing "flexibility products and services" such as distributed solar PV inverters, real-time transactions, demand response, and pricing of reserves that would enable them to obtain electricity from the most flexible resources. Response to these market changes, however, depends on adaptations in the utility regulatory landscape. Nevertheless, the dependence of the modern society on a stable and reliable electricity system require that these innovations should be ongoing throughout the lifetime of the electricity grid infrastructure.

The transition from centralized to decentralized renewable electricity governance animates business-model innovations to address "death spiral" concerns and inefficient resource allocation. REV's core strategy addresses market risks in New York by increasing DER deployment, increasing transparency in utility ownership, incentivizing low-carbon electricity generation, and aligning utility profits with DER deployment [45]. However, as [36, 62] caution, these innovations must not be construed as attempts at regime preservation rather than market adaptations for fostering 'polycentric' business-model innovation. In other words, the REV docket's core strategy positions political and economic innovations of the utility landscape to optimize customer-focused operations and return on environment. For instance, the role of the ESCOs which currently provide only commodity services (e.g., energy efficiency investments) are expanded to include more classes of electricity services including consulting and analytic services to help consumers dynamically manage their energy bills.

\section{Conclusion}

The key objective of this chapter was to evaluate the viability of the Hamel business model and its application to evaluating the New York's REV vision and the state's path for optimizing distributed energy future and customer choice. The Hamel framework proved to be a valuable analytical business model methodology in this context. The chapter reveals that residential and commercial rooftop solar electricity generation systems is expanding in 
New York led by behind-the-meter facilities producing power intended for on-site consumption in homes, office facilities, and commercial buildings. Our findings show that New York utilities are increasingly investing in behind-the-meter renewable energy projects. Utilities favor these customer-side projects which recorded the fastest growth in electricity revenues, sales, and customers in 2016 of 89.4, 78.6, and 68.7\%, respectively.

The chapter sheds lights on the growing influence of business-model innovations and the New York's REV docket in optimizing utility customer choice management and distribute system planning of electricity services. This research shows that implementation of the REV vision in a polycentric fashion offers significant benefits to all customers, not just those that subscribe to them, by generating richer innovations in pricing plans, consumer choice management, and customer analytics to improve utility operations and customer satisfaction. The expansion of renewable electricity market in New York would be impossible without support from state and federal policymakers. Although key polices and market regulations including community choice aggregation, net metering, clean energy fund, dynamic load management, low income affordability, and utility energy efficiency proposals have been proposed and even in some cases implemented in NYS to improve the development of distributed utilities and services, significant improvement in regulatory and market reforms is still required to eliminate market, financial, and economic barriers and skewed incentives that presently impede the efficient evolution of the utility sector. One of the key market development needs is thus to emphasize heavily improvement in the utilities' business-model innovation through external partnerships and suitable organizational structures that promotes an integrated renewable electricity utility market statewide.

\section{Acknowledgements}

This work was supported by the Utility of the Future project that is co-sponsored by the Center for Energy and Environmental Policy (CEEP) at the University of Delaware and the Foundation for Renewable Energy and Environment (FREE).

\section{Conflict of interest}

No potential conflict of interest was reported by the authors.

\section{Author details}

Joseph Nyangon ${ }^{1,2 *}$ and John Byrne ${ }^{1,2}$

*Address all correspondence to: jnyangon@udel.edu

1 Foundation for Renewable Energy and Environment (FREE), New York, NY, USA

2 Center for Energy and Environmental Policy (CEEP), University of Delaware, Newark, DE, USA 


\section{References}

[1] Sioshansi FP. Future of Utilities - Utilities of the Future: How Technological Innovations in Distributed Energy Resources Will Reshape the Electric Power Sector. 1st ed. Amsterdam: Heidelberg: Elsevier, Academic Press; 2016

[2] U.S. Department of Energy. Transforming the Nation's Electricity System: The Second Installment of the QER, Quadrennial Energy Review. Washington, D.C.: U.S. Department of Energy (DOE); 2017

[3] Nyangon J. Distributed Energy Generation Systems Based on Renewable Energy and Natural Gas Blending: New Business Models for Economic Incentives, Electricity Market Design and Regulatory Innovation. Newark, DE: Dissertation, University of Delaware; 2017

[4] U.S. Energy Information Administration. Electricity Data Browser. 2018; Available at: https://www.eia.gov/electricity/data/browser/. Accessed January, 2018

[5] Alonso G, Bilbao S, Valle asd Ed. Economic competitiveness of small modular reactors versus coal and combined cycle plants. Energy. 2016;116:867-879

[6] Nyangon J, Byrne J, Taminiau J. An assessment of price convergence between natural gas and solar photovoltaic in the U.S. electricity market. Wiley Interdisciplinary Reviews: Energy and Environment. 2017;6(3):4-9

[7] Athawale R, Felder F. Residential rate design and death spiral for electric utilities: Efficiency and equity considerations. In: Sioshansi FP, editor. Future of Utilities Utilities of the Future: How Technological Innovations in Distributed Energy Resources will Reshape the Electronic Power Sector. 1st ed. London: Elsevier; 2016. pp. 193-209

[8] Graffy E, Kihm S. Does disruptive competition mean a death spiral for electric utilities? Energy Law Journal. 2014;35(1):1-44

[9] Accenture. The Digitally Enabled Grid: How can Utilities Survive Energy Demand Disruption? United States: Accenture; 2014

[10] Pérez-Arriaga I. Christopher Knittel. Utility of the Future: An MIT Energy Initiative Response to an Industry in Transition. Boston, MA: MIT Energy Initiative; 2016

[11] D'Aprile P, Newman J, Pinner D. The New Economics of Energy Storage. New York, NY: McKinsey \& Company; 2016

[12] Frew BA, Becker S, Dvorak MJ, Andresen GB, Jacobson MZ. Flexibility mechanisms and pathways to a highly renewable US electricity future. Energy. 2016;101:65-78

[13] Fox-Penner PS. Smart Power: Climate Change, the Smart Grid, and the Future of Electric Utilities. Washington: Island Press; 2010

[14] Byrne J, Taminiau J. A review of sustainable energy utility and energy service utility concepts and applications: Realizing ecological and social sustainability with a community utility. Wiley Interdisciplinary Reviews: Energy and Environment. 2016;5(2):136-154 
[15] Loock M. Going beyond best technology and lowest price: On renewable energy investors' preference for service-driven business models. Energy Policy. 2012;40(1):21

[16] Pätäri S, Sinkkonen K. Energy service companies and energy performance contracting: Is there a need to renew the business model? Insights from a Delphi study. Journal of Cleaner Production. 2014;66:264-271

[17] Osterwalder A, Pigneur Y, Clark T, Smith A. Business Model Generation: A Handbook for Visionaries, Game Changers, and Challengers\&Nbsp. Hoboken, NJ: Wiley; 2010

[18] Chesbrough H, Rosenbloom RS. The role of the business model in capturing value from innovation: Evidence from Xerox Corporation's technology spin-off companies. Industrial and Corporate Change. 2002;11(3):529

[19] Shafer SM, Smith HJ, Linder JC. The power of business models. Business Horizons. 2005;48(3):199-207

[20] Provance M, Donnelly RG, Carayannis EG. Institutional influences on business model choice by new ventures in the microgenerated energy industry. Energy Policy. 2011;39(9):5630-5637

[21] Okkonen L, Suhonen N. Business models of heat entrepreneurship in Finland. Energy Policy. 2010;38(7):3443-3452

[22] Behrangrad M. A review of demand side management business models in the electricity market. Renewable and Sustainable Energy Reviews. 2015;47

[23] Richter M. Utilities' business models for renewable energy: A review. Renewable and Sustainable Energy Reviews. 2012;16(5):2483-2493

[24] Funkhouser E, Blackburn G, Magee C, Rai V. Business model innovations for deploying distributed generation: The emerging landscape of community solar in the U.S. Energy Research \& Social Science. 2015;10:90-101

[25] Chesbrough H. Business model innovation: Opportunities and barriers. Long Range Planning. 2010;43(2-3):354-363

[26] McGrath RG. Business models: A discovery driven approach. Long Range Planning. 2010;43(2-3):247-261

[27] Sosna M, Trevinyo-Rodríguez RN, Velamuri SR. Business model innovation through trialand-error learning: The Naturhouse Case. Long Range Planning. 2010;43(2-3):383-407

[28] Lehr RL. New utility business models: Utility and regulatory models for the modern era. The Electricity Journal. 2013;26(8):35-53

[29] Cochran J, Zinaman O, Logan J, Arent D. Exploring the Potential Business Case for Synergies between Natural Gas and Renewable Energy. United States: Joint Institute for Strategic Energy Analysis (JISEA); 2014

[30] Frantzis L, Graham S, Katofsky R, Sawyer H. Photovoltaics Business Models. United States: USDOE; 2008 
[31] Richter M. Business model innovation for sustainable energy: German utilities and renewable energy. Energy Policy. 2013;62:1226-1237

[32] Krapels EN. New York as a clean energy hub. The Electricity Journal. 2016;29(7):23-29

[33] Kindström D. Towards a service-based business model - key aspects for future competitive advantage. European Management Journal. 2010;28(6):479-490

[34] Hamel G. Leading the Revolution: How to Thrive in Turbulent Times by Making Innovation a Way of Life. Boston, Mass: Harvard Business School Press; 2000

[35] Taminiau J, Nyangon J, Lewis AS, Byrne J. Sustainable business model innovation: Using polycentric and creative climate change governance. In: Fields Z, editor. Collective Creativity for Responsible and Sustainable Business Practice: IGI Global. 2017. pp. 140-159

[36] Byrne J, Taminiau J, Seo J, Lee J, Shin S. Are solar cities feasible? A review of current research. International Journal of Urban Sciences. 2017 Sep 2;21(3):239

[37] Byrne J, Hughes K, Rickerson W, Kurdgelashvili L. American policy conflict in the greenhouse: Divergent trends in federal, regional, state, and local green energy and climate change policy. Energy Policy. 2007;35(9):4555-4573

[38] Nicholson S, Jinnah S, Gillespie A. Solar radiation management: A proposal for immediate polycentric governance. Climate Policy. 2018;18(3):322-334

[39] Adil AM, Ko Y. Socio-technical evolution of decentralized energy systems: A critical review and implications for urban planning and policy. Renewable and Sustainable Energy Reviews. 2016;57:1025-1037

[40] Hagel J, Brown JS. Institutional innovation: Creating smarter organizations to scale learning. Deloitte Center for the Edge. 2013:1-22

[41] Amit R, Schoemaker PJH. Strategic assets and organizational rent. Strategic Management Journal. 1993;14(1):33-46

[42] Zhao X, Pan W, Lu W. Business model innovation for delivering zero carbon buildings. Sustainable Cities and Society. 2016

[43] NYPSC. Reforming the Energy Vision: Staff Report and Proposal. Albany, New York: NYPSC; 2014

[44] NYPSC. Proceeding on Motion of the Commission in Regard to Reforming the Energy Vision, Order Adopting Regulatory Policy Framework and Implementation Plan, CASE 14-M-0101. Albany, NY: New York Public Service Commission (NYPSC); 2015

[45] Zibelman A. REVing up the energy vision in New York: Seizing the opportunity to create a cleaner, more resilient, and affordable energy system. IEEE Power \& Energy Magazine. 2016;14(3):18-24

[46] Kauffman R, Zibelman A. New York's reforming the energy vision. Power. 2015;159(5):34

[47] NYPSC. Staff White Paper on Benefit-Cost Analysis in the Reforming Energy Vision Proceeding. Albany, NY: New York State Department of Public Service (NYPSC); 2015 
[48] NYPSC. Proceeding on Motion of the Commission in Regard to Reforming the Energy Vision (CASE 14-M-0101). Staff White Paper on Ratemaking and Utility Business Models. Albany, NY: New York Public Service Commission (NYPSC); 2015

[49] Felder FA, Athawale R. Optimizing New York's reforming the energy vision. Utilities Policy. 2016;41:160-162

[50] Binder JA, Foster PE. Comparing ambitious energy reforms: The German Energiewende and New York state REV. Natural Resources and Environment. 2016;30(4)

[51] Illinois Commerce Commission. ICC Launches NextGrid: Illinois Utility of the Future Study. 2017; Available at: https://nextgrid.illinois.gov/NextGrid_Launch_Release.pdf. Accessed January 20, 2018

[52] Brooks C. The periodic table of the electric utility landscape: A series of visual tools for enhanced policy analysis. The Electricity Journal. 2015;28(6):82-95

[53] Astoria R. On the radicality of New York's reforming the energy vision. The Electricity Journal. 2017;30(5):54-58

[54] Faruqui A, Sergici S, Warner C. Arcturus 2.0: A meta-analysis of time-varying rates for electricity. The Electricity Journal. 2017;30(10):64-72

[55] NYPSC. Order Establishing the Benefit Cost Analysis Framework (14-M-0101). Albany, NY: NY Public Service Commission (NYPSC); 2016

[56] NYPSC. Order on Net Energy Metering Transition, Phase one of Value of Distributed Energy Resources, and Related Matters (15-E-0751, 15-E-0082). Albany, NY: NY Public Service Commission (NYPSC); 2017

[57] Agüero JR, Khodaei A. Roadmaps for the utility of the future. The Electricity Journal. 2015;28(10):7-17

[58] Selviaridis K, Wynstra F. Performance-based contracting: A literature review and future research directions. International Journal of Production Research. 2015;53(12):3505-3540

[59] Cooper J. The innovation platform enables the internet of things. In: Sioshansi FP, editor. Future of Utilities. Utilities of the Future. How Technological Innovations in Distributed Energy Resources Will Reshape the Electric Power. Elsevier; 2016. pp. 91-110

[60] Satchwell A, Cappers P. A framework for organizing electric utility regulatory and business models. The Electricity Journal. 2015;28(8):119-129

[61] Lazar J. Electricity Regulation in the U.S: A Guide. Regulatory Assistance Project: United States; 2011

[62] Hess DJ. The politics of niche-regime conflicts: Distributed solar energy in the United States. Environmental Innovation and Societal Transitions. 2016;19(4):42-50 
